\title{
Elite Predatory Practices in the Budgeting Process of Local Development in Indonesia
}

\section{Muhammad Mahsun}

\begin{abstract}
This article analyses the pattern of relation between local businessmenpoliticians in parliament and the executive elite in budgeting for the local infrastructure development. By using the theory of patronage, cronyism, and predatory state as a framework analysis, this paper provides a theoretical contribution that sees the three theories are complementary to each other. The predatory practices in Indonesia often work in the context of political patronage and cronyism. In this study, the businessmenpoliticians in parliament and executive elites of local government placed as local-state actors relate to each other in the informal networks for the practices of a predatory state. My findings showed that the domination of the businessmen-politicians in local parliament has created a network of patronage politics and cronyism with the executive elite. The businessmen-politicians and the executive elites collaborated to hijack the budgeting process. There has been a monopoly of tenders of local infrastructure development projects. The services exchanged between the businessmen-politicians with the executive elite are public goods.
\end{abstract}

\section{Keywords}

Patronage; cronyism; predatory state; businessmen-politicians; executive elite; budget policy

\section{Introduction}

After the authoritarian New Order regime collapse, the existence of democratic institutions and the rise of decentralization are not necessarily bringing Indonesia's political system truly democratic (see Hadiz 2005; Hadiz 2010). In contrast, for some areas, oligarchic and predatory power systems have grown and developed. Where the interests of the elite group at the local level controlled and driven the local government power. The fading power of the central government had given free space for a small group of local elites (local bourgeoisie or local businessman) to directly control the resources. During the New Order,

\footnotetext{
Muhammad Mahsun is a Lecturer in the Department of Political Science, Faculty of Social and
} Political Sciences, Walisongo State Islamic University.

\section{Corresponding Author:}

Muhammad Mahsun, the Department of Political Science, Walisongo State Islamic University, Semarang, Indonesia.

Email: muhammad.mahsun@walisongo.ac.id 
they are happier to be a client businessman in getting part of the country's economic resources than plunge directly as part of the state elite. After the reforms era, most of them are even more pleased to work directly as a politician. Because then at least they can have closer and direct access to local resources.

This paper examines the existence of the local bourgeoisie that dominated the local parliament in one of the districts in Indonesia ${ }^{1}$. I would like to analyze the pattern of relation between local businessmen-politicians in parliament with the executive elite in budgeting for the local infrastructure development. All this time, the budget policy for infrastructure development is seen as the most vulnerable locus to the practice of collusion and affirmation of the relationship networks of patronage and cronyism. More specifically, two key questions are inter-related, how was the pattern of relation between businessmen-politicians in the parliament and the executive elite in budgeting for infrastructure development. And how this relation affects the implementation of government especially in the area of the policy-making local infrastructure development budget.

I present my discussion in four sections. First, I describe the studies on business and politics then elaborate on the concepts of Predatory State, Patronage, and Cronyism used as the framework of analysis in this article. Second, I briefly explain businessmen-politicians, political parties, and local parliament as the context of the case study. Third, I explore the arena of the establishment of relation networks between businessmen-politicians in parliament and the executive elites. These relation networks work on three important areas, including the budgetary policy arena, the election arena, and the everyday life arena. In my final section, I discuss and elaborate on how patronage and cronyism are linked to predatory state practices.

\section{Literature Review}

\section{Studies on Business and Politics}

The close relation between businessmen and authorities in local government has a significant influence on the policy-making process of local development (see Reno 1995; Agustino 2009; Hidayat 2007). Moreover, businessmen have become members of the parliament who have a role in the policy-making process. There is the possibility that the policy of the development budget will be full of business interests of political actors. Due to their position in the local parliament, they institutionally have a parallel position with the executive elite. This widens the opportunity for the establishment of a political network, such as patronage and cronyism relation. Finally, they are hard to disconnect vested business and political interests in the policy-making, otherwise even spawned predatory practices.

One of the studies on business and politics has addressed the relation between informal power (businessmen and Jawara) with local authorities in Banten (see Hidayat 2007). Hidayat (2007) showed how the relation between

${ }^{1}$ For this publication, the author intentionally did not mention the name of the regency that was the case study. 
businessmen and local leaders in carrying out a local government has led to rentseeking and corruption to restore the funds that have been spent on the campaign. Corruption and rent-seeking can be done through development projects and decision-making within the circles of power in patronage and cronyism relation. This happens easily if the occupying public offices is a person who has an entrepreneurial background. They can create policies that give benefits to the market or expand their businesses.

It also happens in developed countries like the U.S., where money can speak two things: first, to fund a campaign to drive public opinion, and second, to build contacts with the legislature to influence the regulation-making, and indirectly also affect executives. Business influence on the policy of this country shows that procedural development rests on the power of money. Money used in elections largely came from economic society actors, both directly and indirectly part of the state (Mubarak 2008,60).

Leo Agustino $(2011,40)$ with citing to Harris-White (1999) explained that the political-economic investment made by businessmen to support regional head candidates during elections created collusion with the authorities. Collusion could include commitments: (i) manipulate policies for the benefit of businessmen (who endorse them in pre-election), (ii) force the privatization of government assets, and (iii) underhand transactions between businessmen and authorities in government tenders. According to Sugiarto $(2009,485)$, these practices lead to political corruption. Also, it will make access tends to be monopolized by government funders (businessmen), so the public does not have the same opportunity to participate in tenders of government projects. Such governance practices can result in political exclusivism.

\section{Predatory State, Patronage, and Cronyism: Theoretical Considerations}

This study uses the theory of predatory state, patronage, and cronyism as a framework for the analysis. Although the three theories can stand alone in analyzing the socio-political phenomenon, in this paper I deliberately combine and elaborate on them for two reasons. First, the practice of predatory state here is a type of corruption committed by state officials who are working in informal networks of patronage and cronyism. Secondly, in practice, these theories have related work with each other. The practice of a predatory state apparatus in control of public goods often works in the bonds of patronage and cronyism. It can be seen from the experiences of a predatory state that occurred during the authoritarian New Order regime (Hadiz 2005; Robison and Hadiz 2004).

The term predatory state is used to read the reciprocal relation between the state, market, and society in developing countries (Endaryanta 2007, 36). The state is predominantly present in all economic and political structures. In the economic structure, the state elites sought to intervene and control the passage of a dominant market mechanism for accumulating material interests to enrich themselves. These efforts are usually done by building a network relation of patronage and cronyism, both state elites themselves as well as private groups (businessmen). Robison and Hadiz $(2004,42)$ see the predatory state as "the 
invisible hand of market dominates administrative behaviour, where everything is for sale and everything has a price." In this regard, the state took advantage of the business sector's weak and deteriorating conditions, especially to compete fairly with international companies.

Usually, political elites or bureaucrats take over straight away and asking for donations from the businessmen or bribes in return. Those businessmen have been helped by the regime at the time of the financial crisis, and the provision of activities without a fair bidding process. It is as described by Kang $(2004,16)$ :

"The predatory state is one in which the state takes advantage of a dispersed and weak business sector. Political elites pursue outright expropriation; they also solicit "donations" from businessmen who in turn are either "shaken down" by the regime or who volunteer bribes in return for favors, and employ other means as well... Potential state influence over economic life is vast, and those businessmen or groups privileged enough to receive low-interest loans or import quotas will benefit at the expense of others."

Predatory state practice as described by Kang, explains how patronage and cronyism relations between the state actors and private actors work. The interest of the entrepreneur to get protection, ease and subsidies from the state meet the interests of the political elite that requires a lot of outstanding material resources in the business sectors. The sense of mutuality is then created based on the instrumental relation as they liked without any compulsion bond between them. The argument in line with the opinion of $\operatorname{Scott}(1993,77)$ as follows:

"The relationship of patronage as well as an exchange relationship between the two roles, such as bonding dyadic (two person) which primarily involves instrumental friendship in which an individual with political socioeconomic setatus higher (patron) uses influence, power and resources to provide protection and benefits for setatus someone with lower (client). In turn, the client responded by offering general support and assistance, including personal services, to the patron."

In the context of this study, the relations of patronage developed slightly different conceptual offered by Scott, but still depart from Scott's conceptual patronage. Political patronage here is seen as the practice of relation between two people or more (group) in which a collusive practices. Political patronage relations occur between local-state actors, namely businessmen-politicians in local parliament with elite executives require collusion among them. Moreover, the related parties did not always have differences and inequalities in economic resources and politics. Inequalities and status differences can occur only in the control of economic resources, while its political status can have an equal position.

The use of the term "political patronage" here a little bit different from the original concept of traditional patronage, but still requires the agreement on who gets what among political actors who are in the political patronage ties. That is, the definition of "political patronage" here is dissimilar with the term political patronage in terms of interaction with voters at the time of the election, as a study conducted by Chandra (2007), and Kitschelt and Wilkinson (2007). Chandra, for 
example, used the term to describe political patronage social interaction that takes place between voters with political patronage concerning democracy. In essence, the use of the term "political patronage" here is different from patronage in the study of traditional anthropology and political patronage in studying relationships between voters with a politician in an election moment. The terms of political patronage used here refer to the mutual relation between the executive and the businessmen-politicians in the local parliament in public budgeting.

"Cronyism" occurs when a political elite puts someone in a position, chooses someone to get government projects, gives privilege for the business to someone based more on friendship regardless of their qualifications, whether he deserves to get it or not. Options or appointment is not based on bureaucratic rationality. Cronyism is the opposite of the meritocracy system. It is described by Zudenkova (2012) as follows:

"Cronyism is defined as partiality to long-standing friends, especially by appointing them to positions of authority, regardless of their qualifications. Cronyism is contrary in principle to meritocracy, when appointments are made according to an individual's merits, such as intelligence, cridentials and education, determined through evaluation or examination."

"Political cronyism" is used to analyze the reciprocal relations between local-state actors that exchange economic and political resources. The resources of this bond can be exchanged in the form of positions, politics (such as support of political party), material, giving privilege in the areas of business, etc. Those cronyism practices are theoretically demonstrated by Zudenkova (2011) as the behavior of a politician from the incumbent candidate to win the presidential election in preparing members of the cabinet. When deciding or choosing cabinet members to fill certain positions, a lot of politicians select and appoint an old friend who became their cronies, then choose an expert or someone who has a good qualification.

The relation of political cronyism requires some key elements. First, the control of resources or a relatively balanced position between crony people. This is different from the relation that occurs in a relation of political patronage, as described in column I below. Second, reciprocal relations that occur upon approval, which is collusion. Third, low loyalty to each other among them, unlike in client loyalty patronage. This is because there is no dependency due to the economic needs of the unbalanced between the two sides. Fourth, the more important the cronyism relations are in a social network ties based on friendship and economic interests and power. 
Table 1. Patronage and cronyism characters in power politics

\begin{tabular}{|c|c|}
\hline $\begin{array}{l}\text { Column I } \\
\text { Political Patronage } \\
\text { - Different resources } \\
\text { power of economic } \\
\text { or politics between } \\
\text { patron and client } \\
\text { (unequal position) } \\
\text { - Agreement } \\
\text { - Promise } \\
\text { - Collusion } \\
\text { - Average loyalties }\end{array}$ & $\begin{array}{l}\text { Column II } \\
\text { Political Cronyism } \\
\text { - The same resources } \\
\text { power of economic } \\
\text { and politics (equal } \\
\text { position) } \\
\text { - Agreement } \\
\text { - Collusion } \\
\text { - Low loyalties or no } \\
\text { loyalties } \\
\text { - A social network - } \\
\text { based on friendship, } \\
\text { and economic and } \\
\text { political interest. }\end{array}$ \\
\hline
\end{tabular}

Sources: Column I, I calculated from the analysis and interpretation of the study of the practice of political patronage of Putra (1988) and Scott (1993), and column II, the concept of cronyism that was initiated by Khatri, Tsang and Begley (2006) and Brown (2006).

Patronage and cronyism that occurred in the political power is essentially a form of exchange transaction services going on both person and organization. Concerning patronage, as described in column I above requires the exchange of services going from the two sides mutually agreed that contains properties without compulsion, collusion, agreement, the client has loyalty ${ }^{2}$, and has a different control of resources between related agents. Controlling resources can here be economic or political power. These relations can happen between a person or organization that has a political position or an equal position but has a different control of material resources.

Cronyism relation as described in column II rather similar to patronage in that both are based on the form of an exchange transaction services that are reciprocal. Only in relation cronyism does not require any difference in control of the economy and political resources, agreements, commitments are based on the identity and the high loyalty of each of its related agents, as in patronage relation. But what needs to be stressed here is if the two patterns of patronage and cronyism relation are happening and working among state actors and private actors (business sector) or going on between the state and the actors themselves

${ }^{2}$ Although the loyalty is not high as happened in the concept of traditional patronage Scott (1993). 
tend to cause the predatory behavior of state elites and corruption (Brown 2006; Robison and Hadiz 2004; Kang 2004).

\section{Methods}

This study used qualitative research methods, where it is used to generate descriptive data about the words spoken or written, and behavior that can be observed from the one being investigated or the object under study (Hendrarso $2008,166)$. The approach used in this research is a case study approach, where the studies are done by looking at specific cases to get the results of research conducted. In this study, the case of infrastructure development budgets serves as a single case to determine the pattern of relationship that occurs between the politician-businessmen in local parliament with the executive elite government.

The data came from various forms of necessary resources, both primary and secondary data. Primary data here includes data obtained from in-depth interviews with some of the informants, including the members of parliament 2009-2014, elite bureaucrats, local community leaders, members of the Election Commission, a local NGO, academics, local political observers, and local journalists. The secondary data here includes relevant information contained in newspapers, journals, and other important related documents. Secondary data, according to the author, is also important as a data amplifier and supporting primary data from indepth interviews.

\section{Results and Discussion}

\section{Businessmen-Politicians, Political Parties, and Local Parliament}

A large number of local parliament members from the business is inseparable from the condition of the political parties at the local level after the Reform Era. Such as, when a poor system of party institutionalization and party regeneration in preparing candidates for election went into the market, the practice of money politics both at the elite and in the grassroots creates a higher cost of politics and the tendency of political parties to partner with businessmen (Gunawan, pers. comm., March 01, 2012). On one hand, conditions of political parties that do not have strict regulation in screening cadres to come forward as a candidate at the election. And on the other hand, the public is in apathetic and materialistic condition. In this situation, a group of businessmen benefited. They are a group of people who have relatively large economic capital, have a great chance to dominate the political structure, including having a great opportunity to win in the local legislative election.

The domination of businessmen in the local parliament, not only from the major parties but also the smaller parties. The presence of businessmen-politicians who dominate this local parliament is not centralized in one specific party but fragmented in many parties, from big to small. It means, quantitatively, parties that are called the big parties both at a national or local level and have businessman cadre or not at all have relatively balanced representation. Party of the Functional 
Groups (Golkar) only managed to get four seats, four seats of Indonesian Democratic Party of Struggle (PDIP), three seats of Democratic Party (Partai Demokrat), and three seats of National Mandate Party (PAN). Even smaller parties such as Crescent and Star party (Partai Bintang Reformasi) also have three, about the same strength quantitatively as the major parties. The other smaller parties have relatively one or two seats. Quantitatively when referring to the number of seats held by each party, no particular party dominates the local parliament because almost all parties have the same power. In these circumstances, lobbying and compromises of political interests will color a lot in any decision-making process.

\section{The Arena of the Establishment of Relation Networks}

The relation between businessmen-politicians of parliament and the executive elite in the predatory practices work in three areas. Firstly, budget policy arena on infrastructure development -as the locus of this study. Second, the election arena took place in mid-2010, and third, the non-budgetary policy arena and non-election process (everyday life). Both of the latter arenas is the arena of support or legitimacy to the effective operation of network relation strengthened and built in the first arena. In the process of budget policy infrastructure development, there are three of the most effective budget cycles that serve as a locus for building and insisting relations between local state actors (businessmenpoliticians and the executive elite). Three budget cycles include planning and conducting a budgeting cycle that occurred in the executive; budgeting approval process by executive elite and members of the local legislative assembly; and finally budget implementation cycles, particularly in construction project tender bidding process that occurs in the Public Works Department.

In process of conducting and planning a budget for infrastructure development, aplenty dominated by the few political elites -they are a group of businessmen-politicians on the council, district head, and elite bureaucrats/heads of departments. In other words, the process is elitist (SO, pers. comm., August 17, 2011; RAR, pers. comm., March 14, 2012). Network relations are pretty close between them have made the planning and budgeting process of infrastructure development dominated by their business and political interests (DRA, pers. comm., March 15, 2012). Because of the dominance of business and political interests of the elite group of businessmen-politicians and bureaucrats elite, the product design development budget was too far from the people aspirations. As expressed by one member of the council, SO (pers. comm., August 17, 2011), that many local development aspirations are accommodated through planning meetings (Musrenbang) at villages and subdistricts-which are held every yeardo not fit in the budget draft development area. Since the disappointment on Musrenbang process conducted at the district level, in 2011, many sub-district heads (Camat) are reluctant to come to the district to attend the meeting of Musrenbang.

In the process of discussion and implementation of infrastructure development budget, according to the informants, there are still many areas that 
serve as an effective for political maneuver and political lobbying by fellow businessmen-politicians and rulers. These political lobbies are related to the distribution of fees and project tenders. Consequently, development budgeting is directed at building patronage and crony networks for allocating local economic resources.

The process of preparing and discussing the budget that was colored by these political economy transactions, in the end, had an impact on the evaluation of budget implementation that became the mandate of the local parliament members to stagnate. Quite a few local parliament members provide a critical evaluation of the responsibility undertaken by regional heads to Parliament on the implementation of the budget. Although many road construction results are not following existing standards. It is not surprising that the road infrastructure that has been built in less than six months has been badly damaged.

The poor road construction going on in the rural areas is not under the amount of the budget allocated from the budget every year. The amount of physical development budget allocation taken from the budget funds, for example, can be seen from the magnitude of the budget year 2009-2011. In 2009 the budget allocation for infrastructure development reached more than IDR 145 billion, the next year decreased to approximately IDR 135 billion, and rose to 150 billion in 2011, an increase which is quite high. The large budget to finance operations personnel, construction, and maintenance of roads and bridges.

The local head election is also one arena that is used as an instrument for the businessmen-politicians to reassert informal relations with the authorities that they have built in the budgeting process. Intensifying the effort is done by providing the necessary assistance and support regional head candidate, the incumbent in this context, either in the form of social and political assistance (such as support of the masses and the political parties) as well as material support (campaign cost). The financial assistance to the authorities is more came from the big bourgeoisie in the local parliament. While social assistance comes from all bourgeois politics in Parliament that has been building relations in the budgeting process, without exception, the large or small bourgeoisie (UR, pers. comm., March 08, 2012; Helwani, pers. comm., August 19, 2011; S0, pers. comm., August 17, 2011). The problem, for the massive amount of aid the former, according to one local journalist, is quite difficult to find concrete evidence. This is because the process is kept strictly confidential and closed to the public so that the media and civil society groups are quite difficult to preach in the media or reveal it (PWD, pers. comm., March 06, 2012).

The informants in the field explained the purpose of the businessmenpoliticians who provide social support to the political and financial authorities on election 2010. In addition to services reciprocation because previously they got services in the form of project tendering, but also an attempt to legitimize the power to influence, intervene and even control the executive elites on the budgeting process. In principle, this "norm of reciprocity/ balas budi" then forces and binds them to meet each other's needs. Consequently, public resources cannot be avoided to be mutually traded goods by them. 
Also, the exchange services that take place in everyday life without certain periods such as elections and budgeting. Where actors businessmen-politicians, in this regard, are known as individuals who assist with the various hidden interests. As a senior local politician and major businessman, this person often also provides a variety of vital assistance. For example, legal aid services, money, etc., to individuals who become his clients, including the small businessmen in the local parliament, the other members of parliament, NGOs, and elite executives. The services were given by this person to the elite executive, theoretically can be seen as another strategy to maintain and strengthen forms of patronage only between the two groups of actors, is the businessmen-politicians (patron) with local government officials and the Regent (the client).

\section{Explaining Patronage and Cronyism Linked to Predatory State Practices}

The big businessmen-politicians with elite executives have institutionally the same and balance status and position. It means that they were both sitting in a state institution called the legislative and executive constitutional areas that have the same position. However, they are distinguished by the control of economic resources where the local big bourgeoisie in the local parliament has controlled greater economic resources than the executive elite. Therefore, with the power of the money they have, they can control the power of the state apparatus to follow what they want to do. The difference in control of economic resources is becoming one of the main requirements for the local businessman who used to be a client or cronies of the rulers in the New Order period. Then, they can be transformed into a patron for the regional executive elite. Networks of political patronage relations between the two groups of local political elites are deliberately constructed by a group of local capitalists and cronies. Political patronage is a basic strategy to maintain their control over local resources that are within the jurisdiction of the government, including plug-in the capitalist intervention in the realm of regional development policy. In other words, political patronage has been used as a strategy to frame the predatory practices of businessmen-politicians and executive elites.

Efforts to control local resources are done by tying the elite executive government through a "norm of reciprocity" working within patronage politics. Where "reciprocation norm" has a strong moral value-laden and inherent in each actor within the system. In this context, it becomes imperative for a ruler as a client of patron, for example-which has a lot of vital assistance such as political support and substantial capital support at the 2010 local head election, and other support services-deliver projects in a large-scale government development. Businessmen-politicians will give a lot of approval for development budgets proposed by the executive (regional head), although it should be resolved behind the scenes. As a patron, a businessman-politician who has a great influence on the local parliament will play political lobbying against the other businessmenpoliticians. In other words, the person who instilled many services to small businessmen-politicians in the parliament will ask them to agree with his decision. Political patronage relations bonding occurs between the big businessmen- 
politicians with the ruling is no permanent relation. But this relation is needed by both related actors because it gives many advantages.

The success of local entrepreneurs transformed into businessmenpoliticians has made the loss of the government's position as a patron of the local entrepreneurs of small and medium plugged during the New Order regime. The client needs to provide assurance substitution patron base, crisis substitution, and protection of the client's survival has been lost because the clients can satisfy their own vital needs. The need for vital goods and services that have been pursued by the group of businessmen-politicians elsewhere finally brought their bargaining position in degrees are balanced with the group or government bureaucrats. This is consistent with what was said by $\operatorname{Scott}(1993,15)$ that:

"Balance of certain exchanges in patron-client relationships reflect the bargaining power of both actors. This means questioning the extent to which clients need more than the patron client requires. Patron is in a superior position if it controls the vital goods and services that cannot be obtained elsewhere."

In the context of the relation between local entrepreneurs (who is currently a parliament member) with the executive elites under a balanced economy and political power, then the patron-client relationship is broken or cracked and finally turned to the relationship more cronyism. Exchanges and cooperation among them tend to be collusive. The values of friendship and economic interests are considered a mutually beneficial relationship.

The emergence of crony relations among small and medium businesses with executive elites is influenced by several factors. First, the changing political structure after the collapse of the New Order regime. Bureaucrats and the military no longer have the power to control the economic and political situation in the region as well as in the New Order and the birth of political liberalization. Second, the growth of local entrepreneurs to be larger, although still much depend on government projects. Third, the inclusion of small and medium entrepreneurs as parliament members, and most of them are party chairman. The third factor is the most decisive establishment of these relations cronyism. The pattern of relationships cronyism is built with a foundation of transactive and reciprocal between the two groups. In cronyism, both the businessmen-politicians and the executive elites have the same political and economic power balanced, so there is no sense of dependence among them as happened in patronage relations as proposed by Scott (1993). Unfortunately, the networks of relationships are very vulnerable to rupture or fracture, compared to political patronage relations.

The presence of patronage and cronyism networks has been making public goods controlled by local predatory elites. The attitude of the executive elites which establishes the existence of a deposit fee for development projects confirms and perpetuates the practice of predatory state at this local level. Besides, it also is instrumental in further strengthening the bonds of patronage and cronyism among regional officials. These bonds are then further negated by entrepreneurs locally and nationally who are not in a "vicious circle" that they 
form more difficult to compete and fight tenders of local development projects. This means that market competition has been in unhealthy conditions because it has been controlled by state actors. Prosperity and progress of the business sector are only enjoyed by a handful of people. Bonding relationships of patronage and cronyism have made it difficult for each other out in the moral value of reciprocation (mutual hostage). Which in turn requires them to meet the needs and demands of each other.

Thus, what can be seen from the portrait of the power relation between the local bourgeoisie in parliament and the executive elite has not only reflected the establishment of networks of patronage and cronyism but also has provided information that has been present at the local state level predatory character. The network of patronage and cronyism between local elites is used as a frame of predatory practices of the local state actors. Their predatory practices make the public goods like tools and items for personal transactions. In other words, their predatory behavior has been made public goods and other local resources as transected goods for the enrichment of each involved actor.

\section{Conclusion}

The presence of the local bourgeoisie in the post-reform era has spawned the face of an oligarchic local democracy and predatory practices of the elite state officials. The predatory practices work effectively within political patronage and cronyism between local state actors (elite executives and businessmen-politicians in parliament). It suggests that political and economic liberalization after the reform era was not given an equal opportunity to every citizen to participate in public affairs. Those who have money and deploy forces of violence are the most advantaged under democratic institutions. In short, liberal democracy practiced in Indonesia is still in the process of becoming, and full of complexity. In the process of democratization for some areas, there are still many hijacked by the interests of oligarchic elites. Finally, the process of deepening democracy substantially in Indonesia still walking haltingly, due to the many local elites are still predatory character than democratic character.

Therefore, the most important of these studies to scholars who want to study Indonesian politics should be the focus on local politics. This is in line with the expression of Tip Oneil (cited in Agustino, 2009) who said: "all politics is local". In a sense, to know the dynamics of Indonesian politics at the national level would need to provide a point of focus on the complexity of local politics. In particular, the informal practices undertaken by local elites in control of natural resources or public goods for personal gain. Formal powers (executive and legislative) are only used as a shield for local control of natural resources in a way to build informal networks (such as networks of patronage and cronyism) among administrators elite, the executive elite, and businessmen-politicians in the local parliament.[] 


\section{Acknowledgements}

This article is adapted from summary publication of my master thesis which submitted for the degree of Masters in the Department of Politics and Government at Gadjah Mada University, Yogyakarta, Indonesia, 2013.

\section{References}

Agustino, Leo. 2009. Pemilukada dan Dinamika Politik Lokal. Yogyakarta: Pustaka Pelajar.

Agustino, Leo. 2011. Sisi Gelap Otonomi Daerah. Bandung: Widya Padjadjaran.

Brown, Rajeswary Amplavanar. 2006. "Indonesia Corporations, Cronyism, and Corruption.” Modern Asia Studies 40, no. 4 (October, 2006): 953-992.

Chandra, Kanchan 2007, "Counting Heads: A Theory of Voter and Elitee Behavior in Patronage Democracies." In Patrons, Clients, and Policies: Patterns of Democratic Accountability and Political Competition, edited by Herbert Kitschelt and Steven I. Wilkinson, 84-109. UK: Cambridge University Press.

Hadiz, Vedi R.. 2005. Dinamika Kekuasaan: Ekonomi Politik Indonesia PascaSoeharto. Jakarta: LP3ES.

Hendrarso, Emy Susanti. 2008. "Penelitian Kualitatif: Sebuah Pengantar." Dalam Metode Penelitian Sosial Berbagai Alternatif Pendekatan, edited by Bagong Suyanto dan Sutinah. Jakarta: Kencana.

Hidayat, Syarif. 2007. "Shadow State...? Bisnis dan Politik di Provinsi Banten." Dalam Politik Lokal di Indonesia, edited by Henk Schulte dan Gerry van Klinken, 267-303. Jakarta: Yayasan Obor Indonesia.

Kang, David C.. 2004. Crony Capitalism: Corruption and Development in South Korea and The Philippines. UK: Chambridge University.

Khatri, Naresh, Eric WK Tsang, and Thomas M Begley. 2006. "Cronyism: A Cross Cultural Analysis.” Jurnal of International Business Studies 37: 61-75.

Kitschelt, Herbert, and Steven I. Wilkinson. 2007. Patrons, Clients, and Policies: Patterns of Democratic Accountability and Political Competition. UK: Cambridge University Press.

Mubarak, Ahmad Husni. 2008. "Pemilukada dan Shadow State." Dalam Negara dalam Pemilukada dari Collapse State ke Weak State, edited by Gregorius Sahdan et al.. Yogyakarta: IPD Press. 
Putra, Heddy Shri Ahimsa. 1988. Minawang: Hubungan Patron-Klien di Sulawesi Selatan. Yogyakarta: UGM Press.

Reno, William. 2005. Corruption and State Politics in Sierra Leone. New York: Cambridge University Press.

Robison, Richard, dan Vedi R. Hadiz. 2004. Reorganising Power in Indonesia The Politics of Oligarchy in an Age of Markets. London and New York: Routledge.

Scott, James. C.. 1993. Perlawanan Kaum Tani. Jakarta: Yayasan Obor Indonesia.

Sugiarto, Bima Arya. 2009. "Politik Uang dan Pengaturan Dana Politik di Era Reformasi." Dalam Korupsi Mengorupsi Indonesia: Sebab, Akibat, dan Prospek Pemberantasan, edited by Wijayanto dan Ridwan Zachrie. Jakarta: PT. Gramedia Pustaka Utama.

White, Barbara Harris. 1999. How India Work: The Character of The Local Economy. Cambridge: Cambridge University Press.

Zudenkova, Galina. 2011. "Political Cronyism.” Accessed January 15, 2012. http://search.proquest.com/docview/1095319970/13BB1D092305973D12B /10?accountid=13771 pada tanggal 15 Januari 2012 .

\section{Author Biography}

Muhammad Mahsun is a Lecturer in the Department of Political Science, Faculty of Social and Political Sciences, Walisongo State Islamic University. He completed his Masters in the Department of Politics and Government at Gadjah Mada University Yogyakarta. His research interests include political party, democracy, election, and local politics.

Email: muhammad.mahsun@walisongo.ac.id 